\title{
Chromosomal analysis of Centromochlus heckelii (Siluriformes: Auchenipteridae), with a contribution to a Centromochlus definition
}

Correspondence:

Roberto Laridondo Lui roberto.lui@unioeste.br
Submitted February 20, 2020

Accepted June 22, 2020

by Claudio Oliveira

Epub September 04, 2020
Online version ISSN 1982-0224

Print version ISSN 1679-6225

Neotrop. Ichthyol.

vol. 18, no. 3, Maringá 2020

\author{
${ }^{\oplus}$ Samantha Kowalski ${ }^{1},{ }^{\oplus}$ Leonardo Marcel Paiz ${ }^{1},{ }^{\oplus}$ Maelin da Silva ${ }^{2}$, \\ ${ }^{\oplus}$ Amanda de Souza Machado, ${ }^{\circ}$ Eliana Feldberg ${ }^{3}$, \\ ${ }^{-}$Josiane Baccarin Traldi ${ }^{4},{ }^{\circ}$ Vladimir Pavan Margarido ${ }^{1}$ and \\ ${ }^{\circ}$ Roberto Laridondo Lui ${ }^{1}$
}

Historically, there are divergences in the species allocation between Centromochlus and Tatia. This study aimed to generate the first cytogenetic data about Centromochlus and, by analyzing a population of Centromochlus heckelii from the Amazon River basin, to contribute as evidence to a historical taxonomic dilemma. Diploid number of 46 chromosomes and a heteromorphic pair was found in the female karyotypes, thus characterizing a ZZ/ZW sex chromosome system. Pale blocks of heterochromatin were located in centromeric regions of some chromosomes; however, the exclusive female chromosome (W) is almost entirely heterochromatic. AgNORs were detected in terminal position on the short arms of one acrocentric pair in males and two chromosome pairs in females, the acrocentric plus the sex chromosome pair. Notable differences between Centromochlus heckelii and previous data about species of Tatia are: lower diploid number, presence of a sex chromosome system and multiple AgNORs in Centromochlus, while species of Tatia have simple AgNORs and the absence of acrocentric chromosomes. Results in this study show that chromosomal markers could contribute as evidence to taxonomic delimitation studies.

Keywords: Centromochlinae, Cytogenetics, Sex chromosome system, Taxonomy, ZZ/ZW.

1 Universidade Estadual do Oeste do Paraná, Centro de Ciências Biológicas e da Saúde, R. Universitária, 1619, Universitário, 85819-170 Cascavel, PR, Brazil. (SK) samanthakowalski95@gmail.com; (LMP) leonardo paiz@hotmail.com; (ASM) amanda. am.machado14@gmail.com; (VPM) vladimir.margarido@unioeste.br; (RLL) roberto.lui@unioeste.br (corresponding author).

2 Universidade Estadual de Ponta Grossa, Departamento de Biologia Estrutural Molecular e Genética, Praça Santos Andrade, 01, Centro, 84010-330 Ponta Grossa, PR, Brazil. (MS) maelinbio@gmail.com.

3 Instituto Nacional de Pesquisas da Amazônia, Coordenação de Biodiversidade, Laboratório de Genética Animal, Av. André Araújo, 2936, Petrópolis 69083-000 Manaus, AM, Brazil. (EF) feldberg@inpa.gov.br.

4 Universidade Federal do Amazonas, Departamento de Genética, Instituto de Ciências Biológicas, Avenida General Rodrigo Octávio, 6200, Coroado I, 69080-900 Manaus, AM, Brazil. (JT) jositraldi@hotmail.com. 
Historicamente, há divergências na alocação de espécies entre Centromochlus e Tatia. Este estudo teve como objetivo gerar os primeiros dados citogenéticos para Centromochlus e, através da análise de uma população de Centromochlus heckelii da bacia do rio Amazonas, contribuir como evidência para o dilema histórico taxonômico. Foi encontrado o número diploide de 46 cromossomos e um par heteromórfico nos cariótipos das fêmeas, o que caracteriza um sistema sexual ZZ/ ZW. Blocos pálidos de heterocromatina foram localizados na região centromérica de alguns cromossomos; no entanto, o cromossomo exclusivo das fêmeas (W) se apresenta quase todo heterocromático. As AgRONs foram detectadas na posição terminal do braço curto de um par acrocêntrico nos machos e em dois pares cromossômicos nas fêmeas, um par de cromossomos acrocêntricos e o par sexual. Notáveis diferenças entre os dados cromossômicos de Centromochlus heckelii e os dados anteriores das espécies de Tatia são: menor número diploide, presença de sistema de cromossomos sexuais e AgRONs múltiplas em Centromochlus, enquanto espécies de Tatia apresentam AgRON simples e ausência de cromossomos acrocêntricos. Resultados deste estudo mostram que marcadores cromossômicos podem contribuir como evidência para estudos de delimitação taxonômica.

Palavras-Chave: Centromochlinae, Citogenética, Sistema de cromosomo sexual, Taxonomia, ZZ/ZW.

\section{INTRODUCTION}

The Neotropical region is characterized by great biodiversity, and South America has the richest freshwater and marine ichthyofauna in the world (Reis et al., 2016). Siluriformes, popularly known as catfishes, comprises the second largest group of Neotropical freshwater fish, composed by 39 families and about 4,000 valid species (Fricke et al., 2020).

Auchenipteridae consists of 26 genera and 126 species (Fricke et al., 2020) divided into two subfamilies (Centromochlinae and Auchenipterinae), which present some historical internal phylogenetic incongruities (Ferraris, 1996; Soares-Porto, 1998). This family gathers small to medium size fishes, with suborbital groove to lodge maxillary bone and anal fin of male with intromittent organ (Calegari et al., 2019). Auchenipterids are inseminating fishes, a distinctive characteristic also present in Astroblepidae and Scoloplacidae (Spadella et al., 2006; 2012). Moreover, they also present internal insemination and a remarkable sexual dimorphism related to anal fin modification and other parts of the body, such as dorsal and pelvic fins, and maxillary barbels (Birindelli, 2014).

Between the two subfamilies, Auchenipterinae has the highest species richness, embracing 17 genera with 77 species (Fricke et al., 2020), and Centromochlinae is composed of eight genera and 49 species (Fricke et al., 2020). In the recent phylogenetic study by Calegari et al. (2019), Centromochlus Kner, 1858 was restricted to include only Centromochlus heckelii (De Philippi, 1853) and Centromochlus existimatus Mees, 1974, both widely distributed species in the Orinoco and Amazon basins (Soares-Porto, 
1998; Ferraris, 2003, 2007; Akama, Sarmento-Soares, 2007). Centromochlinae is a well-supported clade, and is diagnosed primarily by traits associated to inseminating reproductive system (Soares-Porto, 1998; Birindelli, 2014; Calegari et al., 2019).

Recently, the phylogenetic relationships of Auchenipteridae (Calegari et al., 2019) expanded the classification of tribes in the family from two to nine, and some Centromochlus subgenera previously proposed by Grant (2015) were recognized as distinct genera (Ferrarissoaresia, Duringlanis, and Balroglanis), as well as some species were allocated in Tatia Miranda-Ribeiro, 1911. Nevertheless, Glanidium Lütken, 1874 was also recovered as paraphyletic due to the recognition of Glanidium leopardum (Hoedman, 1961) as a distinct lineage, currently valid as Gephyromochlus leopardus. Three species were allocated into the new genus Duringlanis (Centromochlus altae Fowler, 1945, Centromochlus perugiae Steindachner, 1882 and Centromochlus romani (Mees, 1988)), two in Ferrarissoaresia (Centromochlus ferrarisi Birindelli, Sarmento-Soares, Lima, 2015, and Centromochlus meridionalis Sarmento-Soares, Cabeceira, Carvalho, Zuanon, Akama, 2013), three in the new genus Balroglanis (Centromochlus macracanthus Soares-Porto, 2000, Centromochlus schultzi Rössel, 1962 and Tatia carolae Vari, Ferraris, 2013) and six Centromochlus species were allocated in Tatia (Centromochlus bockmanni (SarmentoSoares, Buckup, 2005), Centromochlus britskii Sarmento-Soares, Birindelli, 2015, Centromochlus concolor (Mees, 1974), Centromochlus orca Sarmento-Soares, Lazzarotto, Rapp Py-Daniel, Leitão, 2017, Centromochlus punctatus (Mees, 1974) and Centromochlus simplex (Mees, 1974)). It is noteworthy that Centromochlus heckelii continues to be allocated in Centromochlus, according to these authors. These alterations have already been inserted in the Eschmeyer's Catalog of Fishes.

Centromochlus had species morphologically very heterogeneous, some of which more similar to other Centromochlinae genera (Birindelli, 2014). Several species have been relocated throughout the entire taxonomy history of the family, mostly between Centromochlus and Tatia. Prior to the most recent phylogenetic study on this group (i.e., Calegari et al., 2019), seven of the 17 species in Centromochlus were not initially described in the genus (Fricke et al., 2020).

Centromochlus was proposed by Kner (1858) to include the new species Centromochlus megalops and Centromochlus aulopygius, the first one designated by Bleeker (1862) as type species. Subsequent studies (e.g., Sarmento-Soares, Martins-Pinheiro, 2008; Sarmento-Soares, Martins-Pinheiro, 2013) allocated several species in Centromochlus, in particular Centromochlus heckelii, which was originally described as Auchenipterus heckelii De Philippi, 1853. Previous to the last study (i.e., Calegari et al., 2019), Tatia comprised 16 valid species and currently has 25 (Calegari et al., 2019; Fricke et al., 2020).

Cytogenetic studies on Auchenipteridae are scarce and restricted to a few species in Ageneiosus, Auchenipterus, Trachelyopterus "Parauchenipterus", Glanidium, and Tatia (e.g., Fenocchio, Bertollo, 1992; Ravedutti, Júlio Jr, 2001; Fenocchio et al., 2008; Lui et al., 2009; Lui et al., 2010; Lui et al., 2013a,b; Lui et al., 2015), and all of them have diploid number of 58 chromosomes. Cytogenetics has contributed to species identification and delimitation in genus and family levels in Auchenipteridae; therefore, provided subsidies for taxonomy decisions. Currently, there is no chromosome study in Centromochlus.

Considering the confuse taxonomy history of Centromochlinae genera (see taxonomic history section in Calegari et al., 2019) and the availability of published chromosomal 
data for Tatia (Lui et al., 2013a), this study aimed to describe the first chromosomal data for Centromochlus. In addition, comparative differences in chromosomal data of Tatia and Centromochlus are herein discussed, and how it can contribute to the allocation of species.

\section{MATERIAL AND METHODS}

Twelve adult individuals (four males and eight females) of Centromochlus heckelii were collected from Solimões River, a tributary to Amazon basin, city of Manaus (AM) (0309'12'S, 5954'20'W) with fishing trawls. The specimens were kept alive in the Catalão Floating Support Base of the Instituto Nacional de Pesquisas da Amazônia - INPA. The specimens were euthanized by clove oil overdose (Griffiths, 2000) for anterior renal cells removal and preparation of mitotic chromosome cell suspensions (Bertollo et al., 1978). The slides were stained with Giemsa 5\% for karyotype studies (Levan et al., 1964) and de-stained with fixative solution 3:1 of methanol and acetic acid, respectively. Afterwards, they underwent $\mathrm{C}$-banding treatment and stained with a solution containing $20 \mu \mathrm{l}$ of anti-fading solution and $0.7 \mu \mathrm{l}$ propidium iodide (Lui et al., 2012) to determine heterochromatin distribution pattern (Sumner, 1972). The slides were de-stained again and subsequently stained by silver nitrate impregnation (Howell, Black, 1980) to detect nucleolus organizing regions (AgNORs), in sequential analysis. The specimens were deposited in the Coleção Zoológica de Peixes do Instituto Nacional de Pesquisas da Amazônia (INPA) under the voucher number INPA 57942.

\section{RESULTS}

The diploid number found in Centromochlus heckelli was of 46 chromosomes for males and females. Thus 14 metacentric chromosomes, 6 submetacentric, 6 subtelocentric and 20 acrocentric chromosomes in males; and 15 metacentric, 6 submetacentric, 5 subtelocentric and 20 acrocentric chromosomes in females (Figs. 1A-C). The difference in karyotype formulas is due to the presence of a heteromorphic pair in the female karyotype, composed of a subtelocentric chromosome $(\mathrm{Z})$ and a large metacentric chromosome (W), which stands out in the karyotype for being the largest in the complement (Fig. 1A). The ZZ chromosomal pair in males corresponds to two subtelocentric chromosomes, which are equivalente to pair 12 (Fig. 1C). Thus, this species presents female heterogamety with a ZZ/ZW sex chromosome system. Heterochromatin was observed in the centromeric regions of some metacentric and acrocentric chromosomes, with pale blocks (Figs. 1BD; Fig. 2). The $\mathrm{Z}$ chromosome shows heterochromatin proximal in the long arm, while the female exclusive chromosome (W) is almost entirely heterochromatic (Figs. 1B-D). AgNORs were detected in two chromosomal pairs in females, both in the short arm terminal position, in the acrocentric pair 20 and in the sex determination corresponding pair (Z and W) (Fig. 1, in box). 


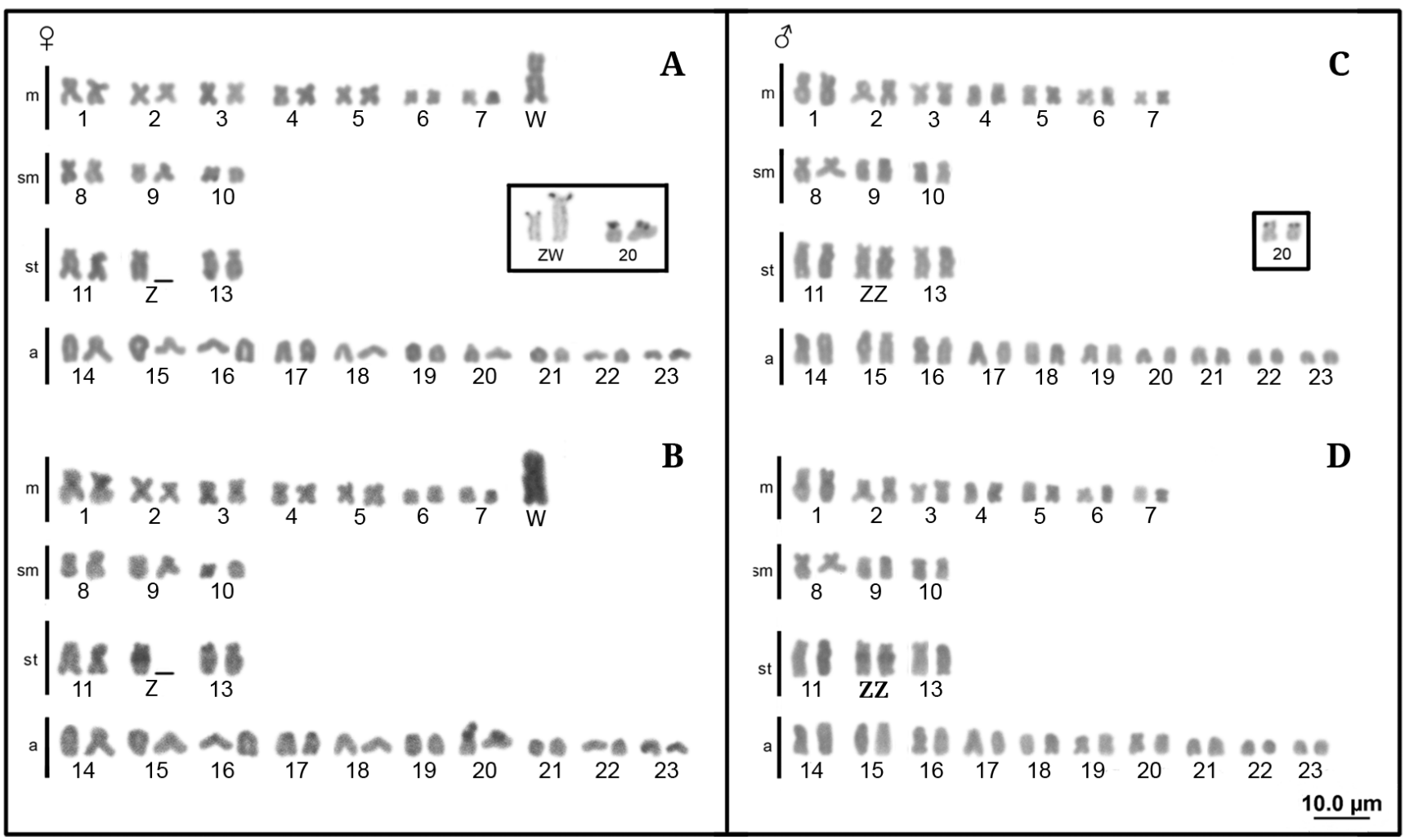

FIGURE 1 I Centromochlus heckelii female (A, B) and male (C, D) karyotypes, stained with Giemsa (A, C) and after C-banding (B, D). Pairs with AgNORs, in box.

\section{DISCUSSION}

Chromosome studies in Auchenipteridae show diploid number of 58 chromosomes for most species (e.g., Ravedutti, Júlio Jr, 2001; Fenocchio et al., 2008; Lui et al., 2009; Lui et al., 2010; Lui et al., 2013a, Lui et al., 2015). Divergent data are observed in Ageneiosus Lacepède 1803, with 56 chromosomes (Fenocchio, Bertollo, 1992; Lui et al., 2013b). This difference can be related to a chromosomal fusion event, confirmed by the presence of ITS (Interstitial Telomeric Sequence) in Ageneiosus inermis (Linnaeus, 1766) (Lui et al., 2013b). The $2 \mathrm{n}=46$ chromosomes detected in Centromochlus heckelii represents the lowest diploid number in Auchenipteridae, whereas $2 \mathrm{n}=58$ chromosomes is probably the plesiomorphic trait of the family (Lui et al., 2013a; Lui et al., 2015). The hypothesis is that independent fusion events in lineages of Auchenipteridae might have occurred during the diversification of species of this group, as Ageneiosus and Centromochlus are not closely related and belong to Auchenipterinae and Centromochlinae, respectively (e.g., Ferraris, 1996; Soares-Porto, 1998; Akama, Britski, 2004; Birindelli, 2014). The two species of Tatia cytogenetically studied, Tatia jaracatia Pavanelli, Bifi, 2009 and Tatia neivai (Ihering, 1930), had 2n=58 chromosomes, yet no acrocentric ones, which seems to be an intrinsic feature of Tatia (Lui et al., 2013a).

Considering the eight species already studied in Auchenipteridae, this is the first report of a sex chromosome system. The superfamily Doradoidea is composed by 
Auchenipteridae and Doradidae, and it is a monophyletic clade supported by many synapomorphies by both morphological and molecular characters (Birindelli, 2014; Callegari et al., 2019). A recent study was the first to describe the presence of a sex chromosome system in a Doradidae species, also a ZZ/ZW system based on the analysis of Tenellus trimaculatus (Boulenger, 1898) (Takagui et al., 2017). Even though they correspond to the same heteromorphic chromosome system, it is evident that the origin events are independent from one another due to the phylogenetic distance between the taxa. Recently, a multiple sex system $\mathrm{X}_{1} \mathrm{X}_{1} \mathrm{X}_{2} \mathrm{X}_{2} / \mathrm{X}_{1} \mathrm{Y}_{1} \mathrm{X}_{2} \mathrm{Y}_{2}$ has also been described in Bunocephalus coracoideus (Cope, 1874) (e.g., Ferreira et al., 2016), a species of Aspredinidae, which differs from those afore mentioned by a male heterogamety. Aspredinidae is considered sister group of the superfamily Doradoidea (Sullivan et al., 2006; Calegari et al., 2019).

Among Siluriformes, most reports of sex chromosomes were in Loricariidae species (e.g., Michele et al., 1977; Oliveira et al., 2007; 2008; Favarato et al., 2015), rarely described in other families. Moreover, it is observed that female heterogametic sex chromosome systems are less common than male heterogametic ones (Takagui et al., 2017). It is noticeable that when a clade has a single type of sex determining mechanism, further analysis may show independent origins of analogous mechanisms (Mank, Avise, 2009), as suggested for salmonid XY systems (e.g., Woram et al., 2003) and Oryzias' multiple systems (e.g., Tanaka et al., 2007), as it obviously corresponds to these Doradoidea species.

The heterochromatin distribution pattern of Centromochlus heckelii differs from the usual of Auchenipteridae. In this species, blocks were verified in the centromeric regions of some metacentric and acrocentric chromosomes (Fig. 1B-D). Most species of Auchenipteridae have terminal blocks but rarely in the centromeric region (e.g., Ravedutti, Júlio Jr, 2001; Lui et al., 2010; Lui et al., 2013a,b; Lui et al., 2015). Furthermore, there is the presence of a conspicuous proximal block on the long arm of the $\mathrm{Z}$ chromosome, and the $\mathrm{W}$ chromosome is almost completely heterochromatic (Fig. 2). Apparent blocks were also observed in the interstitial region of a submetacentric pair in Tatia neivai (Lui et al., 2013a), similar to the one observed on Z chromosome in Centromochlus heckelii but on chromosomes of different morphology (Fig. 2).

The majority of gonochoristic fish species have homomorphic sex chromosomes, and heteromorphic sex chromosomes have been found in roughly $10 \%$ of the karyotyped species (Devlin, Nagahama, 2002). According to Charlesworth et al. (2005), differentiation of sex chromosomes occurs initially by the accumulation of sex-specific alleles in only one of the proto-sex chromosomes. Afterwards, mechanisms that suppress recombination by chromosomal rearrangements and/or accumulation of repetitive DNA sequences among proto-sex chromosome homologues are triggered (Cioffi et al., 2017).

The fact that $\mathrm{W}$ is fully heterochromatic and larger than $\mathrm{Z}$, the second having only one proximal heterochromatin block on the long arm, suggests that the emergence of this large chromosome may have occurred from two probable mechanisms: (1) heterochromatinization of the $\mathrm{W}$ chromosome, which would explain the almost inexistence of euchromatin regions when compared to $\mathrm{Z}$, with evolutionary dynamics similar to the upper vertebrate $W$ chromosomes (Cioffi et al., 2017). In such cases, W is almost entirely heterochromatic and $\mathrm{Z}$ has only one block restricted to the pericentric or telomeric regions, as observed in lower vertebrates, like Characidium Reinhardt, 1867 species (e.g., Vicari et al., 2008; Scacchetti et al., 2015). (2) Heterochromatin amplification, 


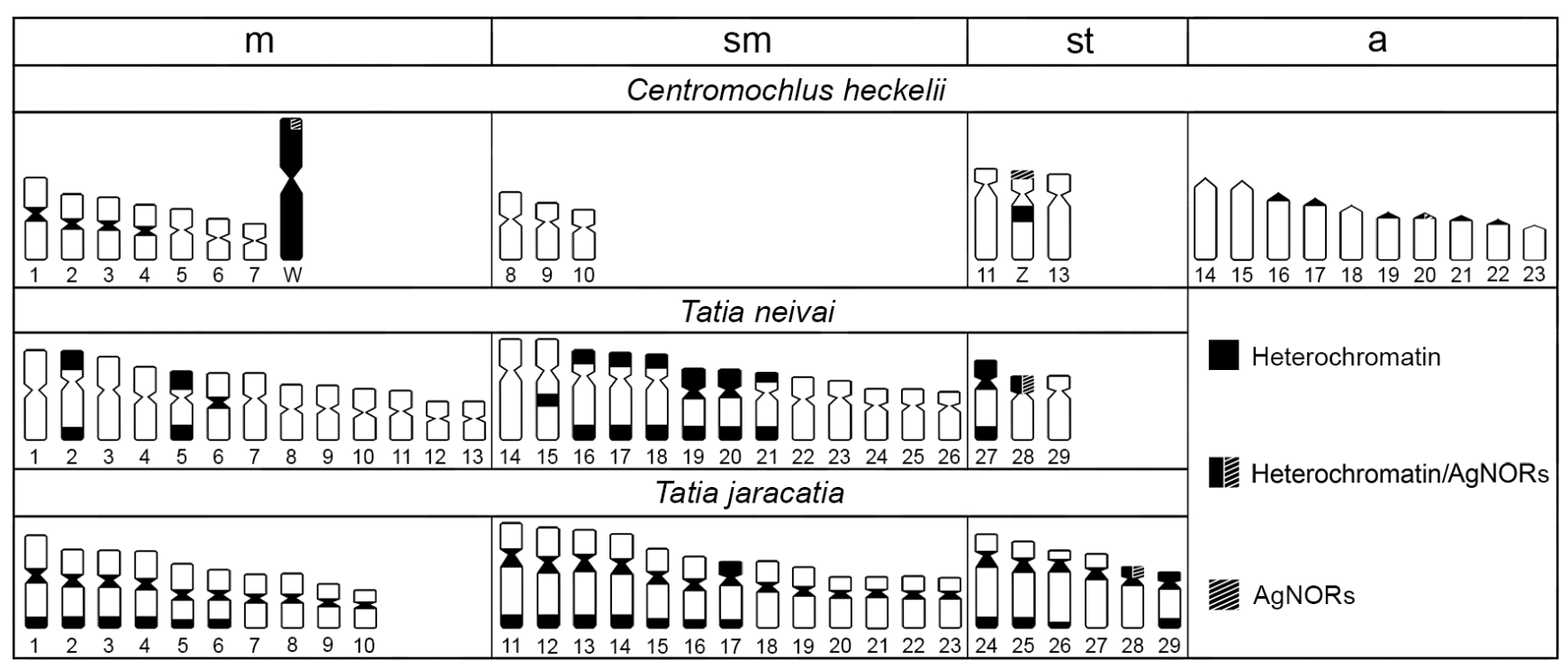

FIGURE 2 I Idiograms representing the karyotype and locations of heterochromatin and AgNORs in Centromochlus heckelii (present study) in comparison to Tatia neivai and Tatia jaracatia (Lui et al., 2013a). m: metacentric chromosomes; sm: submetacentric chromosomes; st: subtelocentric chromosomes; a: acrocentric chromosomes.

which would explain the larger size of $\mathrm{W}$ compared to $\mathrm{Z}$, as observed in Leporinus Agassiz, 1829 species (Characiformes, Anostomidae) (e.g., De Almeida Toledo, Foresti, 2001) and Tenellus trimaculatus (e.g., Takagui et al., 2017), result of heterochromatin segment accumulation by regional replication or tandem duplication (Galetti Jr, Foresti, 1986; Galetti et al., 1995). Strikingly, in many species with differentiated sex chromosomes, the $\mathrm{Y}$ or W is larger than its counterpart (Schartl et al., 2016).

Multiple AgNORs are described for the first time in Auchenipteridae. Regarding the species of Tatia, which have greater historical taxonomic incongruities with Centromochlus, AgNORs are in terminal position on the short arm of a subtelocentric pair (Lui et al., 2013a), similar to populations of Trachelyopterus galeatus (Linnaeus, 1766) (Lui et al., 2009; Lui et al., 2010) and Glanidium ribeiroi Haseman, 1911 (Lui et al., 2015). In Doradidae, AgNORs vary in number and morphology of the carrier pair, yet simple AgNORs in terminal position is considered standard for the family (Milhomem et al., 2008; Takagui et al., 2017).

Centromochlus heckelii had AgNORs in two pairs, including the sex determining pair, which may come from translocation between the chromosomal pairs. During interphase, chromosomes retain their individuality and occupy distinct territories in the nucleus. This conformation, called the "Rabl Model", occurs because each intherphase chromosome follows the course of a primary nuclear filament, where secondary and tertiary filaments extend as lateral projections and form a three-dimensional structure. The centromeres are preferably at a specific nucleus site and the telomeres tend to be at an opposite site, especially on the periphery of the nucleus. As a result, a close arrangement between non-homologous chromosomes may facilitate translocation of rDNA genes between equilocal telomeric regions (Cremer et al., 1982; Cremer, Cremer, 2010).

According to Calegari et al. (2019), Centromochlus and Tatia have represented the 
most complex genera of the subfamily, with a high amount of homoplasies, caused primarily by many species descriptions and reallocations between these genera, undermining taxonomic limits, which highlights the need for alternative tools for species delimitation. Therefore, cytogenetics among Centromochlinae genera showed to be a supporting tool for taxonomy and perhaps phylogenetic informative, assisting the understanding of species allocation. While comparing Centromochlus heckelii and Tatia data, four notable differences are detected: (1) difference in diploid number, (2) absence of acrocentric chromosomes in Tatia, (3) presence of a sex chromosome system in C. heckelii and (4) multiple AgNORs in C. heckelii (Tab. 1). The data presented here, when compared to the literature, show simple chromosomal markers capable of pointing out distinct characteristics among genera. It is important to say that markers were found from classical cytogenetic techniques with potential to assist in future investigations in taxonomy and phylogenetic studies amid Tatia and Centromochlus.

TABLE 1 I Chromosomal differences between Centromochlus heckelii and species of Tatia.

\begin{tabular}{|c|c|c|c|c|c|}
\hline \multirow{2}{*}{ Taxa } & \multicolumn{4}{|c|}{ CHROMOSOME DIFFERENCES } & \multirow{2}{*}{ References } \\
\cline { 2 - 5 } & $\mathbf{2 n}$ & Acrocentric & Sex System & AgNORs & \\
\hline $\begin{array}{c}\text { C. heckelii } \\
\text { T. jaracatia/T. } \\
\text { neivai }\end{array}$ & 46 & 20 chromosomes & ZZ/ZW & Multiple (2 pairs) & Present study \\
\hline
\end{tabular}

\section{ACKNOWLEDGMENTS}

The authors are grateful to the Instituto Chico Mendes de Conservação da Biodiversidade (ICMBio) for the authorization for collection and INPA for the logistical support and availability of laboratory technicians for specimen collection. We are grateful Dr. Jansen A. S. Zuanon (INPA) for identifying the specimens. This study was funded by Fundação Araucária de Apoio ao Desenvolvimento Científico e Tecnológico do Paraná and by the Conselho Nacional de Desenvolvimento Científico e Tecnológico (CNPq).

\section{REFERENCES}

- Akama A. Revisão sistemática dos gêneros Parauchenipterus Bleeker, 1862 e Trachelyopterus Valenciennes, 1840 (Siluriformes, Auchenipteridae). [PhD Thesis]. São Paulo: Universidade de São Paulo; 2004.

- Akama A, Sarmento-Soares LM. Família Auchenipteridae. In: Buckup PA, Menezes NA, Ghazzi MS, editors. Catálogo das espécies de peixes de água doce do Brasil. Rio de Janeiro: Museu Nacional Universidade Federal do Rio de Janeiro; 2007. p.116-20.
- de Almeida Toledo LFA, Foresti F. Morphologically differentiated sex chromosomes in Neotropical freshwater fish. Genetica. 2001; 111(1-3):91-100. https://doi.org/10.1023/A:1013768104422

- Bertollo LAC, Takahashi CS, MoreiraFilho O. Cytotaxonomic consideration on Hoplias lacerdae (Pisces, Erythrinidae). Braz J Genet. 1978; 1:103-20. 
- Birindelli JLO. Phylogenetic relationships of the South American Doradoidea (Ostariophysi: Siluriformes). Neotrop Ichthyol. 2014; 12(3):451-564. https://doi. org/10.1590/1982-0224-20120027

- Bleeker P. Atlas ichthyologique des Indes Orientales Néêrlandaises, publié sous les auspices du Gouvernement colonial néêrlandais: Tome II - Siluroïdes, Chacoïdes et Hétérobranchoïdes. Amsterdam; 1862. https://doi.org/10.5962/ bhl.title. 67474

- Calegari BB, Vari RP, Reis RE. Phylogenetic systematics of the drifwood catfishes (Siluriformes: Auchenipteridae): a combined morphological and molecular analysis. Zool J Linnean Soc. 2019; 187(3):661-773. https://doi.org/10.1093/ zoolinnean/zlz036

- Charlesworth D, Charlesworth B, Marais G. Steps in the evolution of heteromorphic sex chromosomes. Heredity. 2005; 95(2):118-28. https://doi.org/10.1038/ sj.hdy.6800697

- Cioffi MB, Yano CF, Sember A, Bertollo LAC. Chromosomal evolution in lower vertebrates: sex chromosomes in Neotropical fishes. Genes. 2017; 8(10):258. https://doi.org/10.3390/genes8100258

- Cremer T, Cremer C, Baumann H, Luedtke EK, Sperling K, Teuber V, Zorn C. Rabl's model of the interphase chromosome arrangement tested in Chinese hamster cells by premature chromosome condensation and laser-UVmicrobeam experiments. Hum Genet. 1982; 60(1):46-56. https://doi.org/10.1007/ BF00281263

- Cremer T, Cremer C. Cromosome Territories. CSH Perspect Biol. 2010; 2(3):a003889. https://doi.org/10.1101/ cshperspect.a003889

- Devlin RH, Nagahama Y. Sex determination and sex differentiation in fish: an overview of genetic, physiological and environmental influences. Aquaculture. 2002; 208(34):191-364. https://doi.org/10.1016/S00448486(02)00057-1

- Favarato RM, Silva M, Oliveira RR, Artoni RF, Feldberg E, Matoso DA. Cytogenetic diversity and the evolutionary dynamics of rDNA genes and telomeric sequences in the Ancistrus genus (Loricariidae, Ancistrini). Zebrafish. 2015; 13(2):103-11. https://doi. org/10.1089/zeb.2015.1140
- Fenocchio AS, Bertollo LAC. Karyotype, C-bands and NORs of the Neotropical siluriform fish Ageneiosus brevifilis and Ageneiosus atronases (Ageneiosidae). Cytobios. 1992; 72(288):19-22.

- Fenocchio AS, Dias AL, Margarido VP, Swarça AC. Molecular cytogenetic characterization of Glanidium ribeiroi (Siluriformes) endemic to the Iguaçu river, Brazil. Chromosome Sci. 2008; 11(3):61-66.

- Ferraris CJ, Jr. The Auchenipteridae: Putative monophyly and systematic, with a classification of the Neotropical Doradoid catfishes (Ostariophysi: Siluriformes). [PhD Thesis]. New York: City University of New York; 1996.

- Ferraris CJ, Jr. Family Auchenipteridae. In: Reis RE, Kullander SO, Ferraris CJ, Jr, organizers. Check list of freshwater fishes of South and Central America. Porto Alegre: EDIPUCRS; 2003. p.470-82.

- Ferraris CJ, Jr. Checklist of catfishes, recent and fossil (Osteichthyes: Siluriformes), and catalogue of siluriform primary types. Zootaxa. 2007; 1418:1-628. https://doi.org/10.11646/zootaxa.1418.1.1

- Ferreira M, Garcia C, Matoso DA, Jesus IS, Feldberg E. A new multiple sex chromosome system $\mathrm{X}_{1} \mathrm{X}_{1} \mathrm{X}_{2} \mathrm{X}_{2} / \mathrm{X}_{1} \mathrm{Y}_{1} \mathrm{X}_{2} \mathrm{Y}_{2}$ in Siluriformes: cytogenetic characterization of Bunocephalus coracoideus (Aspredinidae). Genetica. 2016; 144(5):591-99. https://doi. org/10.1007/s10709-016-9927-9

- Fricke R, Eschmeyer WN, Fong JD. Eschmeyer's catalog of fishes: Species by Family/Subfamily [Internet]. San Francisco: California Academy of Sciences; 2020. Available from: http:// researcharchive.calacademy.org/research/ ichthyology/catalog/SpeciesByFamily.asp

- Galetti Jr PM, Foresti F. Evolution of the ZZ/ZW system in Leporinus (Pisces, Anostomidae): Role of constitutive heterochromatin. Cytogenet Genome Res. 1986; 43(1-2):43-46. https://doi. org/10.1159/000132296

- Galetti Jr PM, Lima NRW, Venere PC. A monophyletic ZW sex chromosome system in Leporinus (Anastomidae, Characiformes). Cytologia. 1995; 60(4):37582. https://doi.org/10.1508/cytologia.60.375

- Grant S. Four new subgenera of Centromochlus Kner, 1858 with comments on the boundaries of some related genera (Siluriformes: Auchenipteridae: Centromochlinae). Ichthyofile. 2015; 3:1-16. 
- Griffiths SP. The use of clove oil as an anaesthetic and method for sampling intertidal rockpool fishes. J Fish Biol. 2000; 57(6):1453-64. https://doi. org/10.1111/j.1095-8649.2000.tb02224.x

- Howell WM, Black DA. Controlled silverstaining of nucleolus organizer regions with a protective colloidal developer: A 1-step method. Experientia. 1980; 36(8):1014-15. https://doi.org/10.1007/ BF01953855

- Kner R. Ichthyologische beiträge. II. Abtheilung Sitzungsberichte der Akademie der Wissenschaften in Wien, Mathematisch-Naturwissenschaftlich. Klasse. 1858; 26:373-448.

- Levan A, Fredga K, Sandberg AA. Nomenclature for centromeric position on chromosomes. Hereditas. 1964; 52:201-20. https://doi.org/10.1111/j.1601-5223.1964. tb01953.x

- Lui RL, Blanco DR, Margarido VP, Moreira-Filho O. First description of B chromosomes in the family Auchenipteridae, Parauchenipterus galeatus (Siluriformes) of the São Francisco River basin (MG, Brazil). Micron. 2009; 40(5-6):552-59. https://doi.org/10.1016/j. micron.2009.03.004

- Lui RL, Blanco DR, Margarido VP, Moreira-Filho 0. Chromosome characterization and biogeographic relations among three populations of the driftwood catfish Parauchenipterus galeatus (Linnaeus, 1766) (Siluriformes: Auchenipteridae) in Brazil. Biol J Linnean Soc. 2010; 99(3):648-56. https://doi. org/10.1111/j.1095-8312.2009.01389.x

- Lui RL, Blanco DR, Moreira-Filho O, Margarido VP. Propidium iodide for making heterochromatin more evident in the C-banding technique. Biotech Histochem. 2012; 87(7):433-38. https://doi. org/10.3109/10520295.2012.696700

- Lui RL, Blanco DR, Margarido VP, Troy WP, Moreira-Filho O. Comparative chromosomal analysis concerning two species of genus Tatia (Siluriformes, Auchenipteridae). Comp Cytogenet. 2013a; 7(1):63-71. https://dx.doi. org/10.3897\%2FCompCytogen.v7i1.4368
- Lui RL, Blanco DR, Martinez JF, Margarido VP, Venere PC, MoreiraFilho $\mathbf{0}$. The role of chromosomal fusion in the karyotypic evolution of the genus Ageneiosus (Siluriformes, Auchenipteridae). Neotrop Ichthyol. 2013b; 11(2):327-34. https://doi.org/10.1590/S167962252013005000004

- Lui RL, Blanco DR, Traldi JB, Margarido VP, Moreira-Filho O. Karyotypic variation of Glanidium ribeiroi Haseman, 1911 (Siluriformes, Auchenipteridae) along the Iguazu river basin. Braz J Genet. 2015; 75(4-Suppl.1):215-21. https://doi. org/10.1590/1519-6984.10714

- Mank JE, Avise JC. Evolutionary diversity and turn-over of sex determination in Teleost fishes. Sex Dev. 2009; 3(2-3):60-67. https://doi.org/10.1159/000223071

- Michele JL, Takahashi CS, Ferrari I. Karyotypic study of some species of the Family Loricariidae (Pisces). Cytologia. 1977; 42(3-4):539-46. https://doi. org/10.1508/cytologia.42.539

- Milhomem SSR, Souza ACP, Nascimento AL, Carvalho Jr JR, Feldberg E, Pieczarka JC, Nagamachi CY. Cytogenetic studies in fishes of the genera Hassar, Platydoras and Opsodoras (Doradidae, Siluriformes) from Jarí and Xingú rivers, Brazil. Genet Mol Biol. 2008; 31(1-Suppl.0):256-60. https:// doi.org/10.1590/S1415-47572008000200017

- Oliveira RR, Feldberg E, Anjos MB, Zuanon J. Karyotype characterization and ZZ/ZW sex chromosome heteromorphism in two species of the catfish genus Ancistrus Kner, 1854 (Siluriformes, Loricariidae) from the Amazon basin. Neotrop Ichthyol. 2007; 5(3):301-06. https:// doi.org/10.1590/S1679-62252007000300010

- Oliveira RR, Feldberg E, Anjos MB, Zuanon J. Occurrence of multiple sexual chromosomes (XX/XY1Y2 and Z1Z1Z2Z2/ Z1Z2W1W2) in catfishes of the genus Ancistrus (Siluriformes: Loricariidae) from the Amazon basin. Genetica. 2008; 134(2):243-49. https://doi.org/10.1007/ s10709-007-9231-9

- Ravedutti CG, Júlio Jr HF. Cytogenetic analysis of three species of the neotropical family Auchenipteridae (Pisces, Siluriformes) from the Paraná river basin, Brazil. Cytologia. 2001; 66(1):65-70. https:// doi.org/10.1508/cytologia.66.65 
- Reis RE, Albert JS, Di Dario F, Mincarone MM, Petry P, Rocha LA. Fish biodiversity and conservation in South America. J Fish Biol. 2016; 89(1):12-47. https://doi. org/10.1111/jfb.13016

- Sarmento-Soares LM, MartinsPinheiro RF. A systematic revision of Tatia (Siluriformes: Auchenipteridae: Centromochlinae). Neotrop Ichthyol. 2008; 6(3):495-542. https://doi.org/10.1590/S167962252008000300022

- Sarmento-Soares LM, MartinsPinheiro RF. Glanidium botocudo, a new species from the rio Doce and rio Mucuri, Minas Gerais, Brazil (Siluriformes: Auchenipteridae) with comments on taxonomic position of Glanidium bockmanni Sarmento-Soares \& Buckup. Neotrop Ichthyol. 2013; 11(2):265-74. https://doi.org/10.1590/S167962252013000200004

- Scacchetti PC, Utsunomia R, PansonatoAlves JC, Silva GJC, Vicari MR, Artoni RF, Oliveira C, Foresti F. Repetitive DNA sequences and evolution of ZZ/ ZW sex chromosomes in Characidium (Teleostei: Characiformes). PLoS ONE. 2015; 10(9):e0137231. https://dx.doi. org/10.1371\%2Fjournal.pone.0137231

- Schartl M, Schmid M, Nanda I. Dynamics of vertebrate sex chromosome evolution: from equal size to giants and dwarfs. Chromosoma. 2016; 125(3):553-71. https:// doi.org/10.1007/s00412-015-0569-y

- Soares-Porto LM. Monophyly and interrelationships of the Centromochlinae (Siluriformes, Auchenipteridae). In: Malabarba LR, Reis RE, Vari RP, Lucena ZMS, Lucena CAS, editors. Phylogeny and classification of Neotropical fishes. Porto Alegre: EDIPUCRS; 1998. p.331-50.

- Spadella MA, Oliveira C, QuagioGrassiotto I. Spermiogenesis and introsperm ultrastructure of Scoloplax distolothrix (Ostariophysi: Siluriformes: Scoloplacidae). Acto Zool-Stockholm. 2006; 87(4):341-48. https://doi.org/10.1111/j.14636395.2006.00250.x
- Spadella MA, Oliveira C, Ortega H, Quagio-Grassiotto I, Burns JR. Male and female reproductive morphology in the inseminating genus Astroblepus (Ostariophysi: Siluriformes: Astroblepidae). Zool Anz. 2012; 251(1):3848. https://doi.org/10.1016/j.jcz.2011.05.005

- Sullivan JP, Lundberg JG, Hardman M. A phylogenetic analysis of the major groups of catfishes (Teleostei: Siluriformes) using rag1 and rag2 nuclear gene sequences. Mol Phylogenet Evol. 2006; 41(3):636-62. https://doi.org/10.1016/j.ympev.2006.05.044

- Sumner AT. A simple technique for demonstrating centromeric heterochromatin. Exp Cell Res. 1972; 75(1):304-06. https://doi.org/10.1016/00144827(72)90558-7

- Takagui HF, Moura LF, Ferreira DC, Centofante L, Vitorino CA, Bueno V, Margarido VP, Venere PC. Karyotype diversity in Doradidae (Siluriformes, Doradoidea) and presence of the heteromorphic ZZ/ZW sex chromosome system in the family. Zebrafish. 2017; 14(3):236-43. https://doi.org/10.1089/ zeb.2016.1368

- Tanaka K, Takehana Y, Naruse K, Hamaguchi S, Sakaizumi M. Evidence for different origins of sex chromosomes in closely related Oryzias fishes: substitution of the master sex-determining gene. Genetics. 2007; 177(4):2075-81. https://doi. org/10.1534/genetics.107.075598

- Vicari MR, Artoni RF, Moreira-Filho O, Bertollo LAC. Diversification of a ZZ/ZW sex chromosome system in Characidium fish (Crenuchidae, Characiformes). Genetica. 2008; 134(3):311. https://doi. org/10.1007/s10709-007-9238-2

- Woram RA, Gharbi K, Sakamoto T, Hoyheim B, Holm LE, Naish K et al. Comparative genome analysis of the primary sex-determining locus in salmonid fishes. Genome Res. 2003; 13(2):272-80. https://doi.org/10.1101/gr.578503 


\section{Neotropical |chthyology} open 2 Access

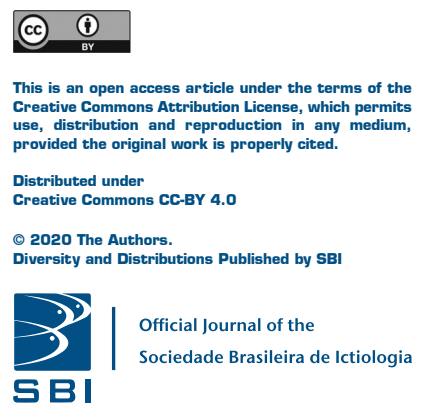

\section{AUTHORS CONTRIBUTION@}

Samantha Kowalski: Conceptualization, Formal analysis, Investigation, Methodology, Writing-original draft, Writing-review \& editing.

Leonardo Marcel Paiz: Formal analysis, Investigation, Methodology, Supervision, Writing-original draft, Writing-review \& editing.

Maelin da Silva: Conceptualization, Investigation, Methodology, Writing-original draft, Writing-review \& editing.

Amanda de Souza Machado: Conceptualization, Investigation, Methodology, Writing-review \& editing. Eliana Feldberg: Conceptualization, Investigation, Project administration, Visualization, Writing-original draft.

Josiane Baccarin Traldi: Conceptualization, Visualization, Writing-original draft, Writing-review \& editing.

Vladimir Pavan Margarido: Conceptualization, Funding acquisition, Methodology, Writing-original draft, Writing-review \& editing.

Roberto Laridondo Lui: Conceptualization, Formal analysis, Funding acquisition, Investigation,

Methodology, Project administration, Supervision Writing-original draft, Writing-review \& editing.

\section{ETHICAL STATEMENT}

Samples were taken under Permanent license of Instituto Chico Mendes de Conservação da Biodiversidade (ICMBio) (SISBIO 49379-1). Anterior renal cells removal and preparation of mitotic chromosome cell suspensions were approved by the Ethical Committee for Animal Use in Experiments of the Universidade Estadual do Oeste do Paraná (Protocol 13/09 - CEEAAP/Unioeste).

\section{COMPETING INTERESTS}

The authors declare no competing interests.

\section{HOW TO CITE THIS ARTICLE}

- Kowalski S, Paiz LM, da Silva M, Machado AS, Feldberg E, Traldi JB, Margarido VP, Lui RL. Chromosomal analysis of Centromochlus heckelii (Siluriformes: Auchenipteridae), with a contribution to Centromochlus definition. Neotrop Ichthyol. 2020; 18(3):e200009. https://doi. org/10.1590/1982-0224-2020-0009 